\title{
Pemberdayaan masyarakat Kelurahan Perkamil dalam mengurangi potensi terjadinya banjir
}

\author{
Tiene M.B. Turangan $\mathbb{B}$ \& Suddin Simandjuntak $*$
}

Universitas Negeri Manado

* suddin173@gmail.com

\begin{abstract}
Abstrak. Permasalahan banjir di Kota Manado merupakan salah satu masalah utama, salah satu titik banjir adalah terutama di Kelurahan Perkamil. Tujuan pelaksanaan teknologi tepat guna biopori mitigasi banjir merupakan salah satu solusi memberdayakan masyarakat untuk (1) mengurangi potensi terjadinya banjir di Kota Manado khususnya Kelurahan Perkamil. (2) mencegah terjadinya kerusakan lingkungan yang semakin parah akibat terjangan air limpasan permukaan tanah. Target khusus yang ingin dicapai adaalah (1) mengurangi aliran air permukaan tanah dari pemukiman atau perumahan; (2) memperbaiki tekstur tanah dengan bahan limbah organic sehingga laju resapan air ke dalam tanah meningkat. Hal ini berdampak pada mitigasi aliran air limpasan permukaan tanah dan konservasi air bawah tanah..

Metode pelaksanaan yaitu melakukan pelatihan terhadap semua kepala lingkungan dan sebagian masyarakat kelurahan Perkamil membuat lubang biopori. Melatih masyarakat mengelola banjir dan limbah rumah tangga dan pekarangan dengan teknik biopori, Kedalaman lubang biopori $100 \mathrm{~cm}$ dan diameter $10 \mathrm{~cm}$, Bahan dan alat, bor tanah, dan paralon., dan limbah organic. Hasil pelatihan semua peserta pelatihan dapat membuat lubang biopori, memahami fungsi dan manfaatnya dalam mitigasi potensi banjir, mengelola sampah organik rumah tangga dan pekarangan. Peserta mengetahui bahwa tanah dapat dipakai sebagai soil biokomposter untuk menghasilkan kompos organik yang bahan bakunya limbah organik rumah tangga dan pekarangan.
\end{abstract}

Kata kunci: infiltrasi; biopori; biokomposter; kompos; air tanah

Abstract. In Manado City flood problem is one of the main problem, one of the flood point is in Kelurahan Perkamil. The objective of implementing the appropriate technology for the biopori flood mitigation is one of the solutions empowering the community to (1) reduce the potential for flooding in Manado city, especially Perkamil village. (2) preventing worsening of environmental damage due to water-surface runoff of the ground. The specific targets to be achieved (1) reduce the flow of land surface water from residential or residential areas; (2) Improve soil texture with organic waste material so that the rate of water catchment into the soil increases, this has an impact on the mitigation of water flow runoff and underground water conservation. Implementation method is to conduct training on all head of environment and some people in the village make Biopori hole, to manage flooding and household waste with biopori technique. the depth of the biopori hole is $100 \mathrm{~cm}$ and a diameter of $10 \mathrm{~cm}$. Materials and tools, dirt drill, paralon, and organic waste. The training results of all trainees can make biopori holes, understand their functions and benefits in mitigating flood potential, manage household organic waste and yard. Participants know that the soil can be used as a soil biocomposter to produce organic compost that raw materials for household organic waste and yard.

Keywords: infiltration; biopori; biokomposter; compost; groundwater

To cite this article: Turangar, T. M. B., \& S. Simandjuntak. 2019. Pemberdayaan masyarakat Kelurahan Perkamil dalam mengurangi potensi terjadinya banjir. Unri Conference Series: Community Engagement 1: 536-544 https://doi.org/10.31258/unricsce.1.536-544

(C) 2019 Authors

Peer-review under responsibility of the organizing committee of Seminar Nasional Pemberdayaan Masyarakat 2019 


\section{PENDAHULUAN}

Mencermati kondisi iklim mulai bulan November sampai dengan awal bulan Maret setiap tahun, kota Manado selalu terancam dengan genangan banjir di tiap kelurahan. Hampir setiap tahun pada bulan Desember sampai dengan Februari intensitas hujan sangat tinggi yang menyebabkan curah hujan juga tinggi. Sesuai pemaparan Wlikota manado Dr. IR.G.S.V. Lumentut SH., M.Si. pada tanggal 10 Juni 2019 di Unima dalam ranngka kerjasama Unima dengan pemerintah kota Manado, ada 3 masalah utama di kota manado. Masalah utama tersebut ialah, banjir air, banjir sampah, dan banjir kendaraan. Sasaran kegiatan pengabdian kepada masyarakat (PKM) yaitu memberdayakan masyarakat dalam meminimalisasi potensi terjadinya banjir, dan pengolahan sampah organik rumahtangga dengan teknologi tepat guna lubang resapan biopori (tenologi LRB). Jayanti et al. (2012) membuktikan bahwa lubang resapan biopori dapat mengurangi dan bahkan menghilangkan aliran air permukaan tanah sebagai salah satu penyebab banjir. Kondisi banjir sekitar bulan januari - Februari 2019 di Manado seperti pada gambar 1 berikut ini.
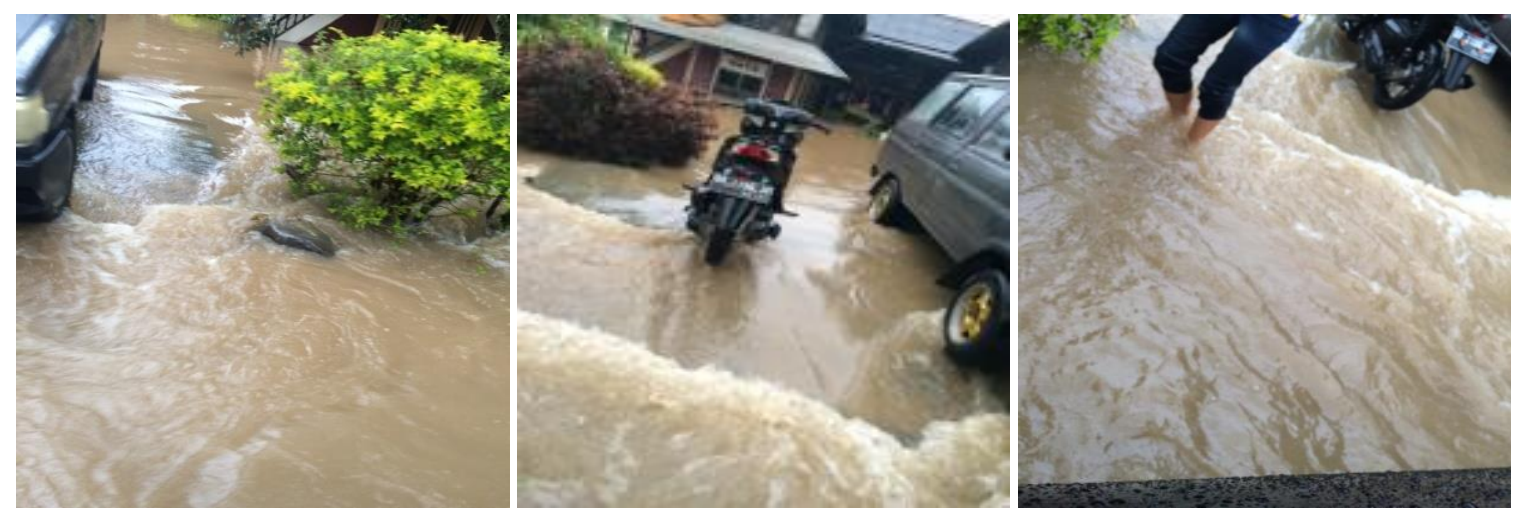

Gambar 1. Banjir Manado tahun 2019

Banjir bandang tahun 2014 membut penduduk kota Manado setiap tahun selalau khawatir akan berulang kembali. Faktanya Kota Manado setiap tahun pasti selalu mengalami banjir, hal ini disebabkan semakin masifnya pembangunan di kota manado dan sekitarnya sehingga lahan yang selama ini merupakan daerah resapan air hujan berubah menjadi lahan kedap air, sehingga semakin memperbesar air limpasan permukaan. Januari dan Februari tahun 2019 banjir yang terjadi baru sebatas menggenangi jalan dan sebagian halaman dan rumah penduduk, parit saluran air tidak lagi mampu menampung air lipasan yang sebagian besar bersumber dari pemukiman dan perumahan penduduk.seprti terlihat pada gambar 1. Luapan banjir ini terjadi disebabkan semakin bertambahnya lahan terbuka di kota Manado dan sekitarnya. Menurut Walikota Manado ada beberapa titik rawan banjir di kota manado diantaranya Kelurahan Perkamil dan Kelurahan Mahawu yang hampir setiap tahun mengalami bencana banjir.

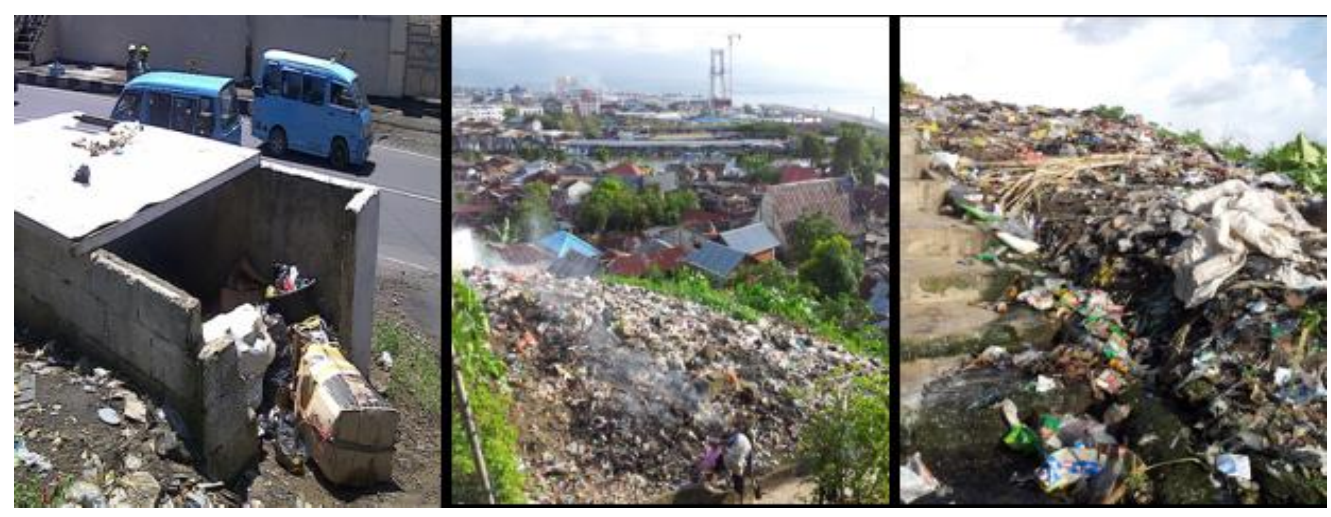

Gambar 2. Lingkungan Permukiman Perbukitan Kota Manado (Novany et al., 2014) 
Masalah sampah kota Manado juga sudah sangat memprihatinkan, tempat pembuangan sampah sumompo yang selama ini menjadi tempat penampungan sampah kota Manado, tidak lagi difungsikan karena sudah penuh. Pemerintah kota Manado sekarang ini membuat program pengelolaan sampah per kecamatan, untuk mengatasi sementara perosoalan sampah ini.sambil menunggu ditemukannya lokasi tempat pembuangan akhir (TPA) sampah yang baru.. Peningkatan volume sampah di TPA, sebagian besar bersumber dari sampah rumah tangga, terutama bahan-bahan organik yang seharusnya tidak perlu dibuang ke tempat sampah seperti terlihat pada gambar 2, tetapi dapat diolah menjadi kompos organik dalam lubang resapan biopori, yang dapat dimanfaatkan sebagai pupuk tanaman pekarangan dan juga dapat dijual untuk menambah penghasilan keluarga. Sampah juga sangat berkontribusi besar terhadap terjadinya banjir di perkotaan, Terutama sampah non organik seperti plastic, dan bentuk sampah lainnya yang sulit terurai dalam lingkungan, sehingga menyumbat saluran air dan sangat mengganggu system drainase kota. Novany dkk., (2014) pengelolaan persampahan sesuai PERDA Nomor 07 Tahun 2006 Kota Manado belum sesuai seperti apa yang diatur dalam perda tersebut. Kegiatan pengelolaan sampah pada tiap kelurahan masih sangat kurang dan tidak ada inovasi dalam penanganan sampah, terutama sampah organik rumah tangga. Peran serta masyarakat dikelurahan Perkamil masih sangat kurang dalam pengelolaan sampah seperti menggunakan metode 3R (Reduce, Reuse, Recycle) tidak terlaksana.Terkait pembiayaan sebanyak 68,98\% masyarakat belum berpartisipasi dalam memberikan iuran yang di tetapkan dalam PERDA.
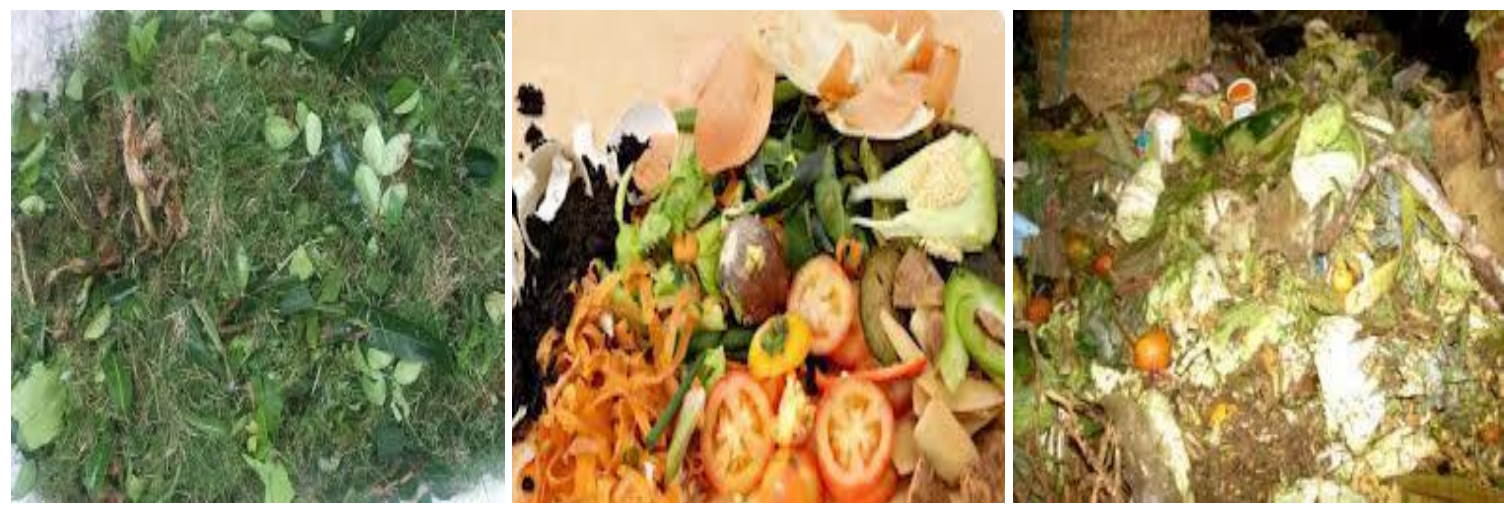

Gambar 3. Sampah organik rumahtangga dan pekarangan

\section{Masalah}

Di kota Manado masalah banjir dan sampah merupakan masalah utama, salah satu titik banjir adalah di Kelurahan Perkamil. Topografi kelurahan ini berbukit dan dialiri sungai yang menjadi penampungan aliran air permukaan dari pemukiman penduduk. Jika alian air permukaan ini dapat dikurangi, maka akan dapat mencegah terjadinya luapan air sungai yang menggenangi pemukiman penduduk. Pembuatan lubang resapan biopori (LRB) dapat mengurangi aliran air permukaan tanah. Satu lubang resapan biopori dengan kedalaman satu meter $(1 \mathrm{~m})$ dan diameter lubang $10 \mathrm{~cm}$, yang diisi sampah organik tiap lubang sebanyak 5 kilogram, dapat meresapkan air kurang lebih sebanyak 5 liter air, maka jika tiap rumah memiliki dua saja LRB akan dapat mengurangi aliran air permukaan menuju sungai secara signifikan, dan mengurangi sampah sebanyak 10 kilogram. Hal ini juga akan dapat mengurangi volume tumpukan sampah pada tempat pembuangan sampah sementara (TPS)

\section{Tujuan Kegiatan Pengabdian}

Tujuan pelaksanaan implementasi teknologi tepat guna biopori mitigasi banjir merupakan salah satu solusi memberdayakan masyarakat untuk (1) mengurangi potensi terjadinya banjir di Kota Manado khususnya Kelurahan Perkamil. (2) mencegah terjadinya kerusakan lingkungan yang semakin parah akibat terjangan air limpasan air permukaan tanah. Target khusus yang ingin dicapai adalah (1) mengurangi aliran air permukaan tanah dari pemukiman atau perumahan; (2) memperbaiki tekstur tanah dengan bahan sampah organic sehingga laju resapan air ke dalam tanah meningkat, hal ini berdampak pada mitigasi aliran air limpasan permukaan tanah dan konservasi air bawah tanah. (3) meminimalisir banjir sampah melalui pemasukan sampah organik ke dalam lubang rsapan biopori, sekaligus menghasilkan kompos organik yang bernilai ekonomi bagi masyarakat. 


\section{METODE PENERAPAN}

Metode pelaksanaan yaitu melakukan pelatihan terhadap semua kepala lingkungan dan sebagian masyarakat kelurahan Perkamil membuat lubang biopori. Melatih masyarakat mengelola banjir dan sampah organik rumah tangga dan pekarangan dengan teknik biopori. Membuat lubang biopori dengan kedalaman $100 \mathrm{~cm}$ dan diameter lubang $10 \mathrm{~cm}$. Bahan dan alat, bor tanah, paralon berlubang., linggis, martil, dan sampah organik.

Kegiatan, dilaksanakan dengan langkah-langkah sebagai berikut:

1. Melakukan survey lokasi yang tepat untuk membuat lubang biopori dengan criteria daerah limpasan air permukaan tanah pada saat hujan.

2. Menentukan titik-titik lokasi lubang biopori dengan jarak antar lubang $100 \mathrm{~cm}$, semua titik ditancapkan patok kayu agar sasaran pembuatan jelas dan sistimatis.

3. Pelatihan dilaksanakan di kantor Kelurahan Perkamil, yang dimulai dari pukul 09.00 pagi sampai jam 12.00. Dua jam pertama diawali dengan pre test untuk mendapatkan pengetahuan awal masyarakat mengenai penanggulangan banjir dan sampah dan mengenai manfaat lubang resapan biopori, kemudian dilanjutkan dengan memberikan penjelasan secara teoritis, dengan menunjukkan gambar alat-alat dan bahan yang digunakan, dan memutarkan video cara pembuatan lubang resapan biopori dilanjutkan tanaya jawab dan diskusi. Bagian ini diakhiri dengan post test untuk mengukur tingkat pemahaman masyarakat tentang manfaat LRB untuk menanggulangi potensi terjadinya banjir dan cara mengelola sampah organik rumahtangga dan pekarangan.

4. Kira-kira satu jam dimanfaatkan untuk demonstrasi pembuatan lubang resapan biopori sekitar kantor kelurahan oleh tim dan kemudian dilaksanakan oleh para kepala lingkungan dan peserta lainnya. Bagian ini merupakan evaluasi akhir untuk melihat pemahaman dan ketrampilan dalam mengimplementasikan teknologi tepat guna LBR dalam mengelola banjir dan sampah organik di lingkungannya masing-masing.

5. Lubang biopori diisi sampah organik rumahtangga dan pekarangan, agar menarik fauna tanah untuk memakan dan mengurai sampah tersebut dan membuat lubang subbiopori secara horizontal maupun vertical yang memudahkan air meresap ke dalam tanah dan sekaligus memperbaiki tekstur tanah yang mempengaruhi porositasnya.

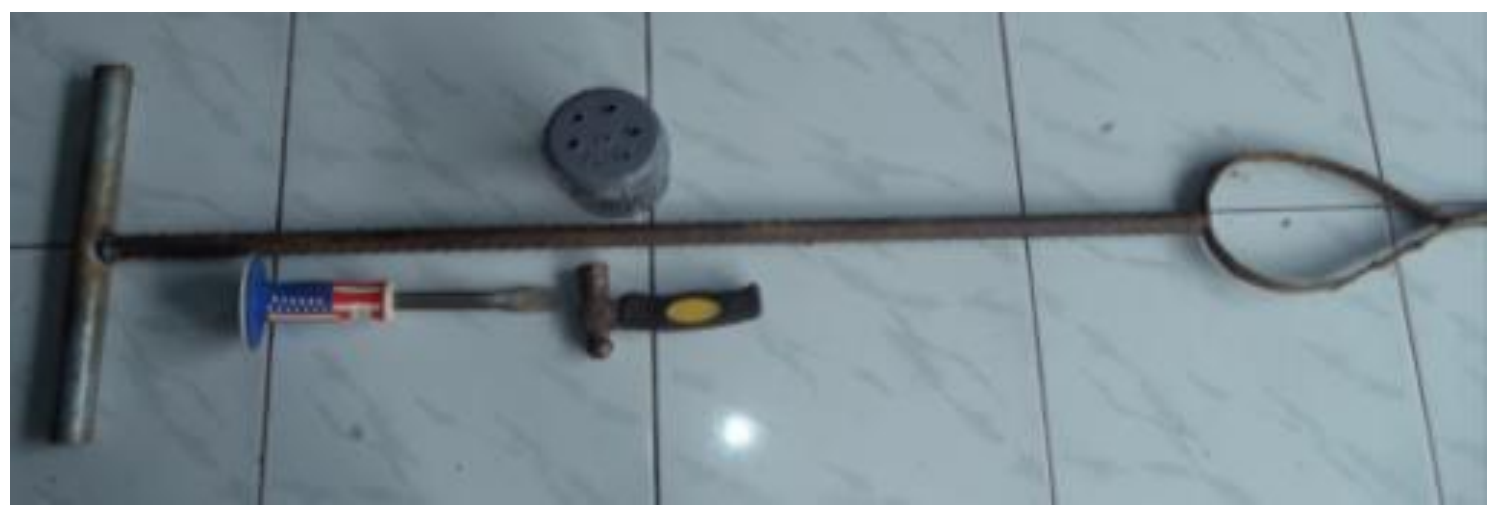

Gambar 4. Peralatan membuat LBR

Skema Transfer Ipteks kepada Mitra dapat digambarkan sebagai mana pada Gambar 5. 


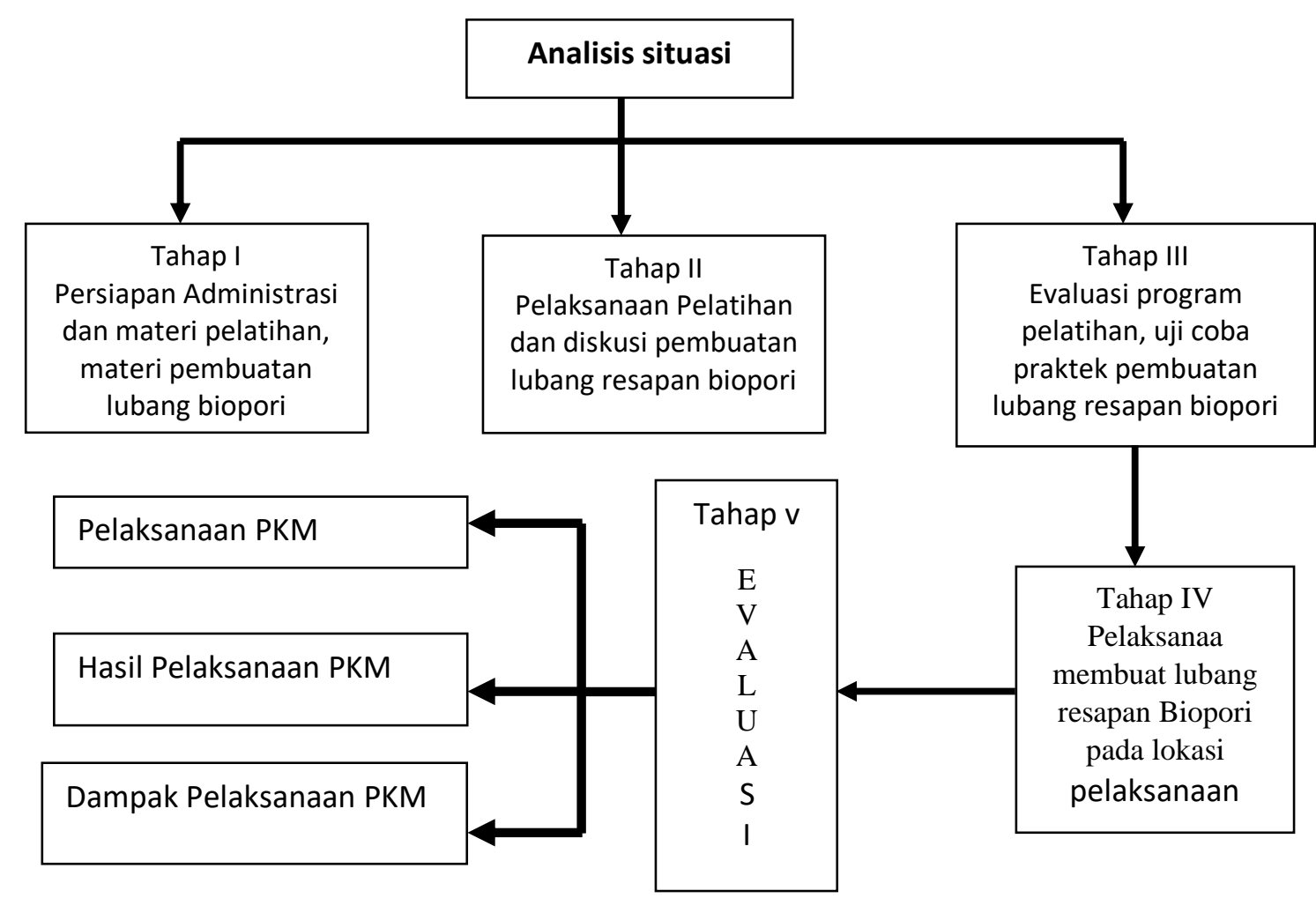

Gambar 5. Model Pelaksanaan PKM di Kelurahan Perkamil kota Manado

\section{PEMBAHASAN}

Lubang resapan biopori (LRB) merupakan lubang yang dibuat secara vertikal ke dalam tanah dengan tujuan untuk meningkatkan laju infiltrasi air hujan ke dalam tanah. Pembuatan lubang resapan biopori secara langsung akan memperluas bidang permukaan peresapan air, seluas permukaan dinding lubang. Lubang resapan biopori merupakan lubang silindris yang dibuat dalam tanah dengan diameter 10-30 cm, dengan kedalaman ideal 100 $\mathrm{cm}$, tetapi tidak melebihi kedalaman muka air tanah. Lubang tersebut kemudian diisi dengan sampah organik agar terbentuk sub-biopori secara horizontal oleh aktivitas organisme tanah dan akar tanaman. Sampah organik perlu selalu ditambahkan ke dalam lubang biopori yang isinya sudah menyusut karena proses pengomposan.. Kompos dalam lubang biopori dapat memperbaiki tekstur dan profil tanah, sehingga tanah akan lebih gembur dan mudah meresapkan air ke dalam tanah. Selain memperbaiki tekstur dan profil tanah, juga kompos akan meningkatkan keragaman biota tanah yang sangat berperan dalam membuat lubang-lubang biopori dalam tanah seperti cacing tanah dan biota tanah lainnya.

Semakin dalam LRB semakin luas penampang resapan semakin besar dan cepat infiltrasi air ke dalam tanah, terutama pada tanah yang homogen karena pengaruh beda tinggi serta luas tampang resapan semakin besar. Pada kondisi tanah yang relatif homogen semakin dalam LRB maka debit air yang dihasilkan akan semakin besar karena beda tinggi energi yang terjadi pada LRB maka tekanan semakin besar, kecepatan resapannya ikut meningkat sehingga luasan penyebarannya semakin luas seperti nampak pada Gambar 6 (Aziz, 2012).

Kompos dalam lubang biopori juga dapat dimanfaatkan sebagai pupuk organic pada tanaman pekarangan atau pada lahan pertanian dan sekaligus memperbaiki tingkat kesuburan lahan melalui peningkatan bahan organic tanah dari kompos biopori. Lubang resapan biopori juga berfungsi sebagai biokomposter atau soil komposter. Lubang resapan biopori memiliki multifungsi yaitu fungsi sebagai reasapan air dapat mengurangi aliran air permukaan tanah (run off) sekaligus mencegah banjir, mengkonservasi air bawah tanah sebagai sumber air bersih sehingga tidak terjadi kekeringan dan krisis air bersih; fungsi sebagai komposter mengurangi volume sampah organik yang bersumber dari rumahtangga, menghasilkan pupuk yang bermanfaat untuk menyuburkan tanaman. 


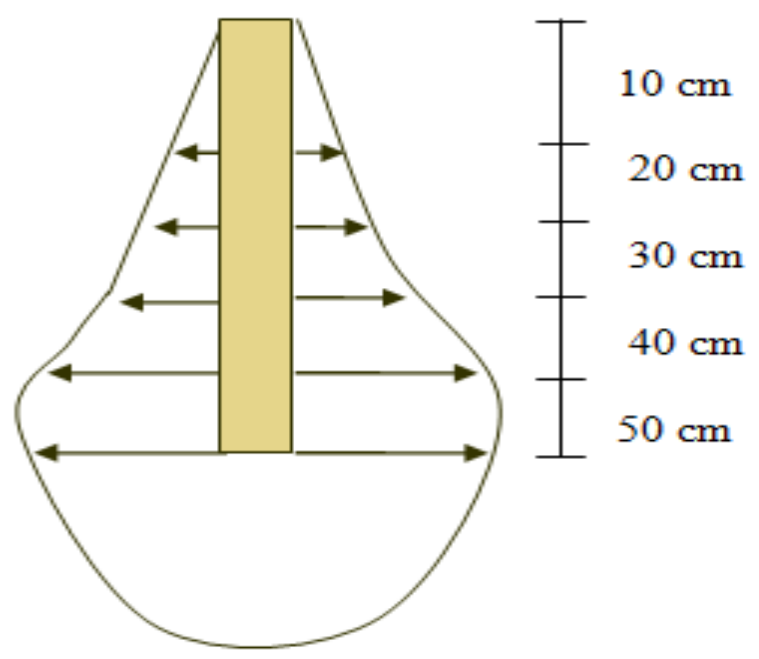

Gambar 6. Pola resapan LRB arah horisontal pada kedalaman yang berbeda.

Peserta yang hadir mengikuti pelatihan selain 8 orang kepala lingkungan juga diikuti 22 orang masyarakat sekelurahan Perkamil. Sebelum materi disampaikan dilakukan lebih dahulu pre-test, untuk mengetahui pengetahuan peserta pelatihan tentang penanganan banjir dan sampah, dan sesudah pemanyampaian materi selesai dilakukan post test untuk melihat sejauh mana peserta dapat menerima serta memahami cara penanganan serta pengelolaan banjir dan sampah. Hasil evaluasi seperti terlihat pada grafik Gambar 6 cukup menggembirakan, ternyata peningkatan pemahaman peserta tentang materi penanggulangan banjir dan pengelolaan sampah rumah tangga pada post test sangat memuaskan sesuai dengan tingkat pendidikan peserta. Hal ini juga menunjukkan keseriusan peserta mengikuti pelatihan, hal yang sama terlihan pada saat demonstrasi pembuatan lubang resapan biopori, peserta serius memperhatikan dan mengamati cara membuat lubang bipori tersebut seperti terlihat pada gambar 7B dan 7C, selanjutnya beberapa peserta kepala lingkungan membuat LRB.

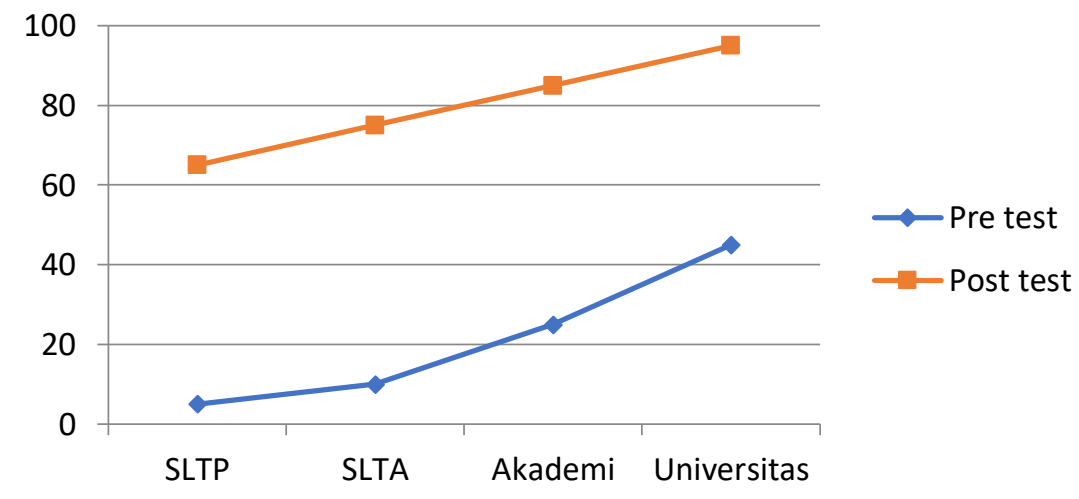

Gambar 7. Hasil Evaluasi pemahaman peserta pelatihan
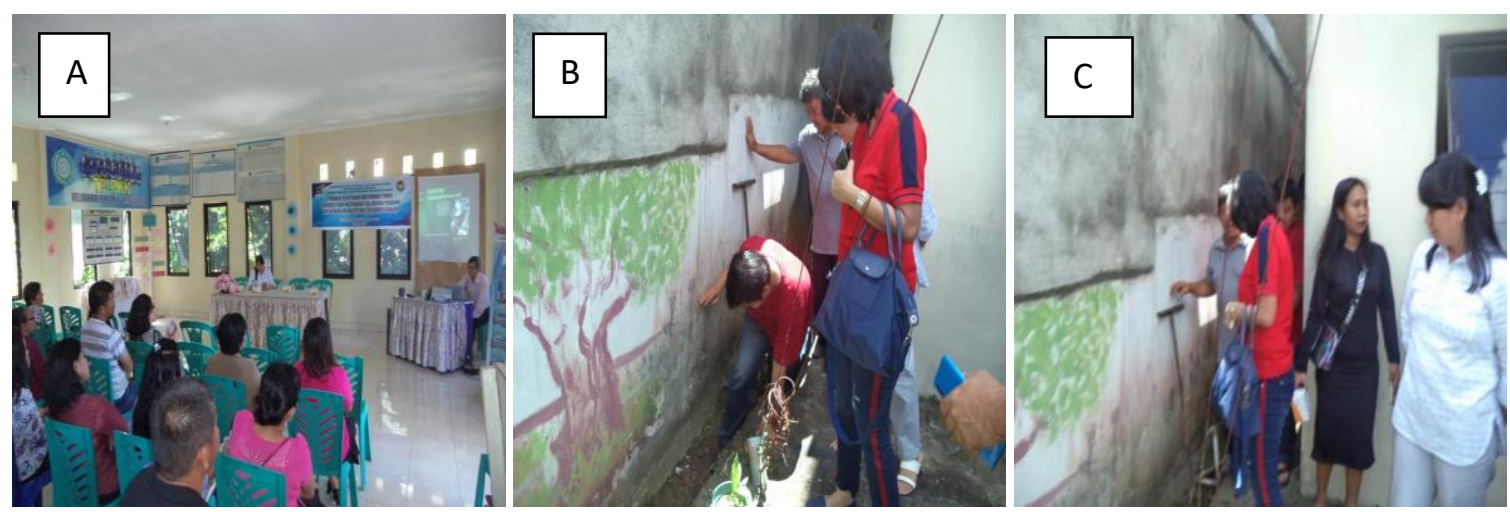

Gambar 8. Mengikuti penyampaian materi dan demo pembuatan LRB. 
Lubang resapan biopori dibuat pada parit yang merupakan tempat air mengalir pada saat hujan turun, LRB pada parit ini akan meresapkan air ke dalam tanah sehingga mengurangi volume air yang masuk ke dalam sungai. Sebagian peserta mempraktekkan membuat lubang resapan biopori khususnya para kepala lingkungan, agar dapat memberi petunjuk pada masyarakat di lingkungannya masing-masing.

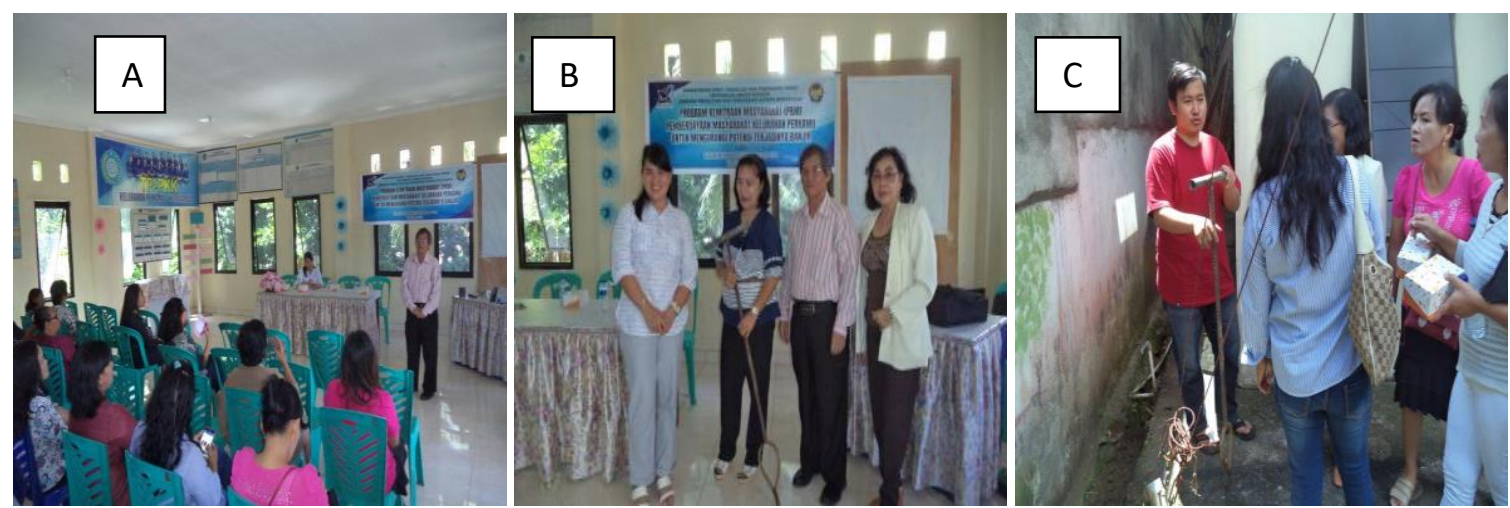

Gambar 9. Pelaksanaan Evaluasi dan demonstrasi pembuatan LBR

Gambar 8A situasi pada saat peserta mengikuti test akhir (post test), gambar 8B seorang ibu kepala lingkungan memperagakan bor tanah, dan gambar $8 \mathrm{C}$ peserta diskusi dengan tim cara membuat LRB.. Gambar 9A peserta membuat lubang resapan biopori, 9B tim narasumber menjawab pertanyaan peserta tentang LRB, dan $9 \mathrm{C}$ berfoto bersama lurah perkamil, anggota DPR dan sebagian peserta.

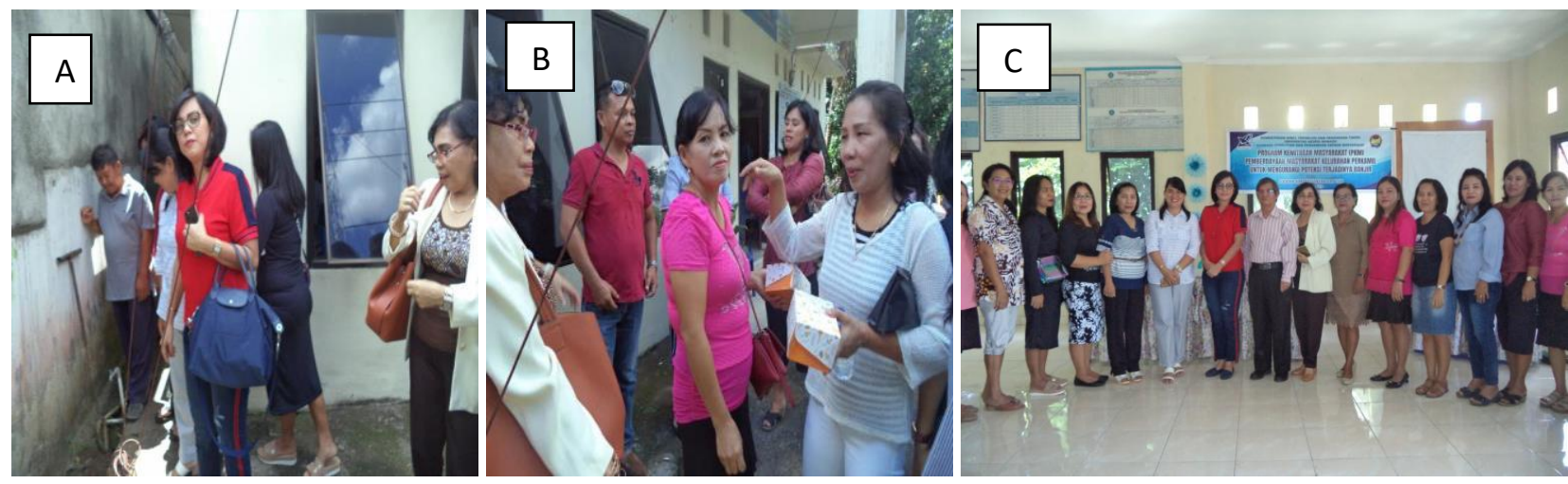

Gambar 10. Diskusi para peserta dengan narasuber dan foto bersama
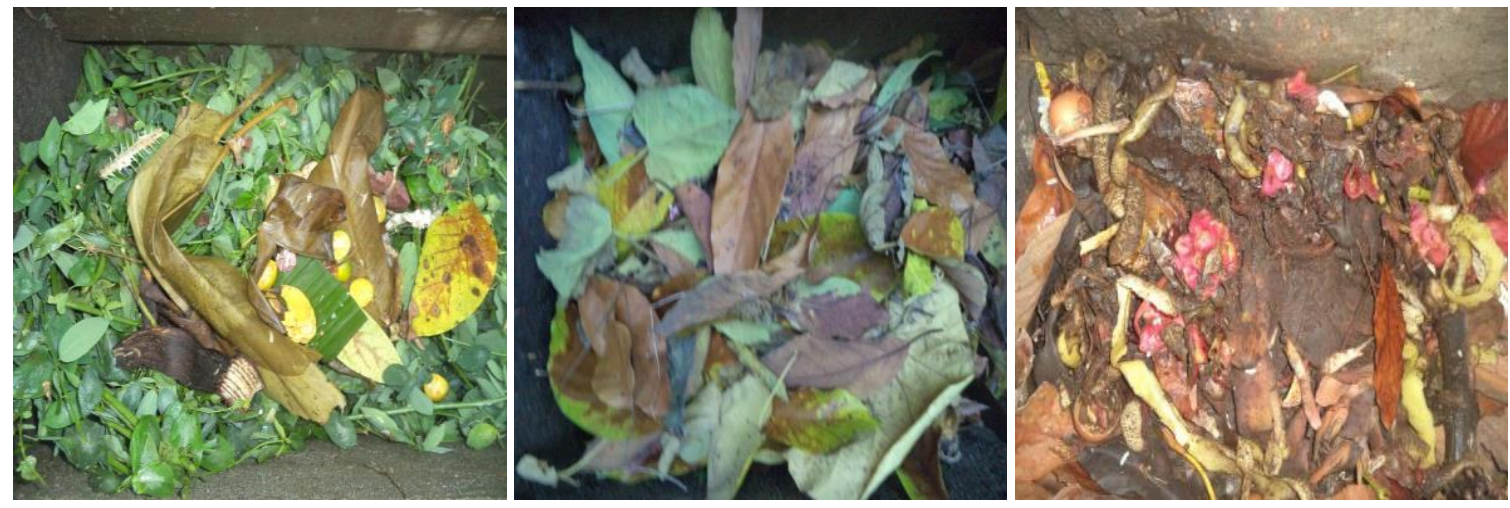

Gambar 11. Limbah organik rumahtangga dan pekarangan 
Gambar 11 merupakan limbah rumah tangga dan pekarangan yang akan dimasukkan pada lubang resapan biopori, sekaligus sampah organik yang akan dikomposkan dalam LRB. Sanjaya dkk.,(2017) membuktikan laju infiltrasi pada LRB terjadi pada saat sampah organik telah membusuk atau sudah menjadi kompos dan proses pembusukan paling cepat terjadi pada LRB yang diisi sampah organik dapur atau yang isi lubang resapan bioporinya dominan sampah dapur. Namun demikian laju infiltrasi air ke dalam tanah juga tetap dipengaruhi oleh kondisi lingkungan seperti jenis tanah dan iklim. Hal yang sama juga dikemukakan Darwia dkk. (2017) berdasarkan hasil uji bahan organik yang dimasukkan dalam LRB yaitu sampah rumah tangga karena aroma atau bau sayur-sayuran dan sisa makanan yang sangat kuat dan manis sehingga mampu menarik lebih banyak mikroba atau hewan pengurai yang membentuk lebih banyak pori tanah secara horizontal maupun vertikal

Keunggulan teknologi tepat guna biopori dalam mitigasi terjadinya potensi banjir dan pengelolaan sampah organik rumah tangga, antara lain mudah pelaksanaannya, murah biayanya dan manfaatnya sangat baik bagi masyarakat. Kompos organik yang dihasilkan dari lubang resapan biopori cukup berkualitas dengan kandungan unsura hara NPK yang baik. Harga jualnya Rp3000,- per kg, hal ini dapat membantu ekonomi keluarga jika dilakukan secara serius. Kelemahan lubang resapan ini jika berada pada jenis tanah yang padat seperti tanah liat, dan tanah berbatu. Pada tanah liat infiltrasi air ke dalam tanah kurang baik dan sangat lambat,perlu waktu untuk memperbaiki tekstur tananh, dan pada tanah berbatu sulit membuat LRB terutama untuk mencapai kedalaman ideal. Pada intensitas hujan $50 \mathrm{~mm} / \mathrm{jam}$ kondisi kategori hujan lebat, laju peresapan air tiap lubang 3 liter per menit sama dengan 180 liter/jam. Lubang resapan biopori dengan diameter lubang $10 \mathrm{~cm}$ dan kedalaman $100 \mathrm{~cm}$ dapat menampung 7,8 liter sampah organik artinya tiap LRB dapat memuat sampah organik rumah tangga 2 sampai 3 hari baru penuh. Fakta ini menujukkan bahwa jika LRB sebanyak 20 buah maka akan dapat menampung sampah organik rumahtangga dan pekarangan sebanyak $20 \times 7,8$ liter sama dengan 156 liter sampah organik, Hal ini sangat signifikan mengurangi volume sampah ke tempat pembuangan sampah (Yohana et al., 2017).

Tingkat kesulitan pengelolaan banjir dan sampah terkait pembiayaan sebanyak 68,98\% masyarakat belum mau berpartisipasi dalam memberikan iuran yang di tetapkan dalam PERDA. Hal ini menyebabkan pengangkutan sampah terkendala, dan terjadi penumpukan dan pembuangan sampah secara sembarangan. Sulitnya merubah perilaku masyarakat untuk peduli lingkungan yang bersih dan sehat, hal ini harus dilakukan sejak dini dalam level pendidikan yang paling rendah sampai pada pendidikan tinggi. Merubah kebiasaan buruk orang dewasa merupakan kesukaran tersendiri yang mungkin akan berubah melalui program kemitraan masyarakat seperti kegiatan ini.

\section{KESIMPULAN}

Pelaksanaan PKM pemberdayaan masyarakat kelurahan Perkamil dalam mengelola sampah dan mencegah terjadinya banjir dapat dikatakan berhasil, teknologi tepat guna yang disampaikan $90 \%$ dapat dipahami dan diterima masyarakat serta menyatakan akan segera melaksanakannya pada lingkungan masing-masing. Respon peserta pelatihan sangat positif hal ini terlihat dari antusiasme masyarakat dalam melakukan praktek uji coba pembuatan LRB. Teknologi LRB menjadi solusi tepat untuk mengatasi potensi terjadinya banjir dan mengelola sampah organik rumah tangga dan pekarangan di kelurahan Perkamil. Masyarakat juga memahami betapa pentingnya melakukan konservasi air bawah tanah sebagai sumber air bersih di masa yang akan datang, terutama pada musim kemarau. Metode pelaksanaan PKM sesuai dengan kondisi masyarakat peserta pelatihan sesuai hasil post test. Kegiatan ini perlu dilanjutkan pada tingkat yang lebih luas meliputi Kecamatan agar dampaknya dapat lebih nyata dan signifikan terhadap mitigasi banjir dan sampah.

\section{UCAPAN TERIMA KASIH}

Ketua tim pelaksana bersama seluruh tim menyampaikan terimakasih kepada Rektor Universitas Negeri Manado yang memberikan dana dalam pelaksanaan kegiatan PKM ini melalui LPPM Unima serta memfasilitasi pelksanaan kegiatan ini. Disampaikan juga terimakasih kepada ketua LPPM dan staf yang membantu pengurusan administrasi pelaksaan PKM dan penyelesaian seluruh kegiatan, demikian juga ucapan terimakasih kepada mahasiswa yang terlibat dalam kegiatan ini. 


\section{DAFTAR PUSTAKA}

Aziz, U. A. 2012. Kajian Kapasitas Serap Biopori dengan Variasi kedalaman dan Perilaku Resapannya. Jurnal Konstruksia 4(1).

Darwia, S., Ichwana, \& Mustafril. 2017. Laju Infiltrasi Lubang Resapan Biopori (LRB) Berdasarkan Jenis Bahan Organik Sebagai Upaya Konservasi Air dan Tanah. Jurnal Ilmiah Mahasiswa Pertanian Unsyiah 2(1).

Jayanti, M. H. D., D. L. Setyowati, \& Tukidi. 2012. Potensi Pemanenan Air Hujan (Rain Water Harvesting) sebagai Pendukung Unnes Konservasi. Geo Image 1(1).

Novany, L., V. A. Kumurur, \& I. L. Moniaga. 2014. Analisis Pengelolaan Persampahan di Kelurahan Sindulang Satu Kecamatan Tuminting Kota Manado. Sabua 6(3): 321-331

Sanjaya, W., K. B. Christian, D. Gunaran, \& E. K. Budirahardjo. 2017. Pengukuran Laju Infiltrasi Lubang Resapan Biopori dengan Pemilihan Jenis dan Komposisi Sampah di Kampus I UKRIDA Tanjung Duren Jakarta. Jurnal Teknik dan Ilmu Komputer 6(22).

Yohana, C., D. Griandini, \& S. Muzambeq. 2017. Penerapan Pembuatan Teknik Lubang Biopori Resapan Sebagai Upaya Pengendali Banjir. Jurnal Pemberdayaan Masyarakat Madani 1(2)

https://doi.org/10.21009/JPMM.001.2.10 